\title{
Religious Violence in the Middle East: Military Intervention, Salafi-Jihadism and the Dream of a Caliphate
}

\author{
Emran El-Badawi \\ University of Houston, Houston, USA
}

\begin{abstract}
From the beginnings of Wahabism in the 18th century to the so called Islamic State of Iraq and the Levant (ISIL, ISIS) violence has occasionally been justified in the name of Islam, which is problematic for secular and traditional scholars alike. This paper demonstrates that there are three complex, interrelated causes for this violence: foreign military intervention, Salafi-Jihadism and a utopian state founded upon faith and justice, i.e. a caliphate.

Keywords: Jihad, caliphate, salafi, islamic state, ISIS, ISIL, al-qaeda, muslim brotherhood, hamas, hezbollah, wahabism, taliban, Arab Spring, Iranian revolution, war on terror, gulf war, cold war, israeli-arab war, syrian civil war
\end{abstract}

\section{Introduction}

The so-called "Islamic State" (IS, ISIS, ISIL), by virtue of its name, forcibly imposed upon the world a religious as well as political agenda. Notorious for its gruesome execution videos, and sophisticated use of media propaganda IS killed over 9 thousand civilians in 2014 alone, the majority of which were Muslims. ${ }^{1}$ Yet IS asserts itself as the sole authentic carrier of Islam—an otherwise diverse religious body of 1.6 billion people, boasting fourteen hundred years of history. Its political agenda is realized with every city, province and territory it conquers from the all but collapsed governments of Iraq and Syria. Its signature claim and most salient undertaking has been the return of the Islamic Caliphate, fusing classical Islamic tradition with modern political warfare. However, as a state it is unrecognized by all its neighbors in the Middle East; and as an embodiment of Islam, it has been completely rejected by Islamic clergy and the public faithful.

One should, therefore, ask the question, from where does IS obtain its legitimacy for its approximately 30 thousand plus fighters? ${ }^{2}$ How Islamic is the so-called "Islamic State?” Why does IS justify barbaric violence against Sunnis, Shi'ites, Christians and Yazidis is in the name of Islam? The fact that such minorities and still other more ancient as well as obscure groups have called greater Iraq and Syria home for two millennia is a living testament to the inherent tolerance and pluralism of traditional forms of Islam. So what are the "root

Emran El-Badawi, Ph.D., Associate Professor of Middle Eastern Studies, Department of Modern and Classical Languages, University of Houston.

Correspondence concerning this article should be addressed to Emran El-Badawi, 618 Agnes Arnold Hall, University of Houston, Houston, Texas 77204, USA.

${ }^{1}$ Human Rights Office of the High Commissioner for Human Rights; United Nations Assistance Mission for Iraq Human Rights Office, Report on the Protection of Civilians in Armed Conflict in Iraq: 6 July-10 September 2014, Geneva and Baghdad: United Nations and High Commission on Human Rights, 2014, 1.

2 The estimates for how many ISIS fighters are in Iraq and Syria vacillate greatly. For an estimate by the CIA in late 2014 see Jim Sciutto, Jamie Crawford and Chelsea Carter, "ISIS can 'muster' between 20,000 and 31,500 fighters, CIA says,” CNN, September 12, 2014. 
causes" for the sprouting of IS's poisonous ideology and how can we eliminate them? The answers to such questions are complex and hotly debated, among academics and policymakers alike. In order for us to get a complete understanding of IS we first need to examine the social, political and economic struggles that lead to the rise and menacing grip of violent religious fundamentalism in the name of Islam. This examination will take us through the Wahabi ideology of oil rich Arab gulf states, to the Salafi school which rose in the political and socio-economic turmoil of Egypt and greater Syria, and the spread of Salafi-Jihadism as a direct result of US military intervention.

\section{Wahabism and Sunni Islamic Revival (18th-20th Century)}

A pact has been made. The year is 1744 . The place is Nejd, a province located in the central and eastern deserts of the Arabian Peninsula. Two men are seizing their destiny and changing the world. The first is Muhammad b. Sa'ud (d. 1765), Emir of the town of al-Dar'iyyah, and after whom the modern nation of Saudi Arabia is named. The second man, whose appetite for religious revival led him to seek out the most renowned Islamic scholars of his day traversing Arabia, Syria and Iraq, who returned reluctantly to his hometown of 'Uyaynah where he would be cast out for a botched pact between him and the Emir of that city, is equally famous - or infamous. He is none other than Muhammad b. 'Abd al-Wahab (d. 1792), after whom the Wahabi movement is named. Ibn 'Abd al-Wahab gave his pledge of allegiance (bay'ah) to Ibn Sa'ud, who would go on to conquer Arabia and spread the ideology of Wahabism. ${ }^{3}$

The teachings of Wahabi ideology are found readily in the numerous works of its prolific and equally dogmatic founder. Its overarching theology centers around reclaiming the unity (tawhid) of the one and only God. Its epistemology emanates from a literalist reading of hugely problematic body of prophetic tradition (hadith) and cherry picked Qur'an passages, the return to the three founding generations of Islam (salaf) as well as re-enactment of their deeds where necessary. Thus, the Muslim faithful in Arabia and throughout the Muslim world, who for generations buried their saints in above ground tombs, illustrated their holy icons and sought favor and healing through petitioning holy men and women, were accused overnight of committing blasphemy. He openly condemned Sufis (i.e. mystically and culturally inclined Muslims), Shi' 'ites (whom he called rafidah, i.e. rejecters of faith), Jews, Christians (nasara, i.e. Nazarenes) - all of whom were native to the Middle East—and anyone else who did not fit into his puritanical Sunni vision. ${ }^{4}$ In doing so, Ibn 'Abd al-Wahab was bringing into practice teachings of ultraconservative Sunni-Hanbali jurists and theologians-notably Ibn Taymiyyah (d. 1328) and Ibn Qayyim al-Jawziyyah (d. 1350)—whose sectarian sensibilities—especially the former's incitement against the Shi'a and Sufiyyah-was typically relegated to the realm of theory, or understood in the post-antebellum 13th century when the Mongols had conquered much of the Middle East.

This context and its theoretical underpinnings were all but lost on Ibn 'Abd al-Wahab and his firebrand reformation. Most importantly history credits Ibn 'Abd al-Wahab for being the first modern Muslim revivalist to declare other Muslims apostates (kuffar), accuse them of committing idolatry (shirk) and innovation (bid'ah), and at times waging a religious war (jihad) against them. ${ }^{5}$ It is important to note that the cultural background of Wahabism was that of early 18th century Nejd. Its tribalism and warfare, reflected the region's remote,

\footnotetext{
${ }^{3}$ Natana DeLong-Bas, Wahabi Islam: From Revival and Reform to Global Jihad, London; New York: I.B. Taurus, 2007, 34-35 illustrates Ibn Sa'ud rather than Ibn 'Abd al-Wahab as the main impulse behind the conquests.

4 On Ibn 'Abd al-Wahab’s unequivocal condemnation of the Shi'ah see DeLong-Bas, Wahabi Islam, 84-90.

5 Ibid., 19-22, 62-65, 221.
} 
un-cosmopolitan and sterile nature, the likes of which remained unconquered by the great Ottoman or Safavid empires. ${ }^{6}$

However, Muhammad b. 'Abd Al-Wahab was not the only Islamic revivalist (mujaddid) of his age to "purify" the Islamic faith from its popular, syncretistic and alternate confessional forms of worship. The Islamic world had always been a locus of international trade and a global network of scholarship. By the 18th century itinerant Sunni scholars crossing between the Middle East, North Africa and Indian Subcontinent made the pilgrimage to Mecca and Medina, often studying among teachers in the peninsula for years. Among their ranks was Shah Wali Allah (d. 1762) of Delhi, India, whose Sunni revival emerged from and later transcended its Sufi origins. ${ }^{7}$ That being said Sunni revivalism was a blip on the radar of Islamic tradition in the Middle East and beyond. It is critical to acknowledge that most Muslims in the 18th century belonged to the mystical Sufi stripe-merging the ancient legal Islamic tradition with native cultural practices from the Middle East, North Africa, India and Southeast Asia. Even today, Muslims are by and large descendants of converts to Sufi Islam, the overwhelming majority of which converted after $1500 \mathrm{CE} .{ }^{8}$

Back in Arabia, the ebb and flow of perpetual tribal warfare would conquer the Sa'udi state itself twice over the next two centuries. What then can explain the success Wahabi ideology, through such precarious and incredible circumstances? And how has its legacy thrived to this day and profoundly shaped the world in which we live?

\section{Oil Wealth and the Prestige of Wahabi Ideology}

Oil and other fossil fuels have shaped the modern world. But the Middle East is not known for an abstract notion of "carbon democracy," but represents rather the standard model of the "rentier state"-a nation where the flow of oil gushes louder than the voice of its people. ${ }^{9}$ Moreover, the "oil curse" about which many specialists have investigated is not limited to influencing the politics of the region. Religion, especially Wahabi ideology, owes its triumph to the triumph of the Saudi oil industry.

The year is now 1902. 'Abd Al-'Aziz Al-Sa'ud (d. 1953) has finally conquered Riyadh and put a decisive end to the Al-Rashid dynasty. He is a brilliant general and is able to defeat the remnants of the collapsed Ottoman empire during and immediately after World War I. over the next three decades, his tribesmen would conquer Arabia from east to west, wresting the title "custodian of the two holy mosques" located in the holy cities of Mecca and Medina from Sharif Husayn b. 'Ali (d. 1931). Sharif Husayn's alliance with the British could not save him, but it breathed new life into his line with the creation of three new, artificial Arab states, Syria (1922), Iraq (1922) and Jordan (1923), to be ruled by his sons with varying success for some time. ${ }^{10}$

${ }^{6}$ Ibid., 7 correctly asserts Wahabism as an indigenous movement emerging from within Nejd as an independent province, and not a "reaction" to Ottoman or British colonial power.

7 Ahmad Dallal, “The Origins and Objectives of Islamic Revivalist Thought, 1750-1850,” Journal of the American Oriental Society, 113.3 (1993), 341-359.

8 The rise of popular, Sufi oriented Islam in Marshall Hodgson's "late middle period” of Islamic civilization (ca. 1250-1500) coincides with the spread of the faith in Central, Southern and Southeast Asia thereafter (ca. 1500-). For more Cf. Marshall Hodgson, The Venture of Islam, Volume 2: The Expansion of Islam in the Middle Periods, Chicago: University of Chicago Press, 1977, 211, 466, 499; Richard Easton, The Rise of Islam and the Bengal Frontier, 1204-1760, Berkeley; Los Angeles; London: University of California Press, 1993, 30-31, 71-91.

${ }^{9}$ For more see Timothy Mitchell, Carbon Democracy: Political Power in the Age of Oil, London; New York: Verso Books, 2011, 1-2, 201 n.4.

10 The fate of Hashemite royalty varied greatly between these three nations. Their power over Syria not last even one year before the French bombed out of their new sphere of influence. In Iraq the Hashemite monarchy lasted until 1958, and the Hashemite Kingdom of Jordan remains until today. 
By 1932, Al-Sa 'ud founded the modern Kingdom of Saudi Arabia and immediately opened up his land to oil exploration. Between 1936-1988 the marriage between transnational American oil companies-beginning with the Standard Oil of Californian (SOCAL) - and kings from Saudi Arabia and other states in the Gulf Cooperation Council (GCC) would grant the Arabian peninsula unimaginable wealth, power and influence around the world. This period saw the efflorescence of the famed Arabian American Oil Company (ARAMCO), founded in 1943 and rebranded as Saudi ARAMCO in 1988. The region was swimming in petrodollars, and this would have major consequences for the spread of Wahabi ideology throughout the world.

The economic boom witnessed by the GCC was not accompanied by any form of liberalism or secularism to speak of-quite the contrary. Growing oil wealth meant the reach and potency of Wahabi ideology was limitless. This ideology was, much like barrels of oil upon which it depended, processed, packaged and exported all over the world. Karen Armstrong describes this episode as follows,

The soaring oil price created by the 1973 embargo-when Arab petroleum producers cut off supplies to the US to protest against the Americans' military support for Israel—gave the kingdom all the petrodollars it needed to export its idiosyncratic form of Islam. The old military jihad to spread the faith was now replaced by a cultural offensive. The Saudi-based Muslim World League opened offices in every region inhabited by Muslims, and the Saudi ministry of religion printed and distributed Wahabi translations of the Quran, Wahabi doctrinal texts and the writings of modern thinkers whom the Saudis found congenial, such as Sayyids Abul-A'la Maududi and Qutb, to Muslim communities throughout the Middle East, Africa, Indonesia, the United States and Europe. In all these places, they funded the building of Saudi-style mosques with Wahabi preachers and established madras as that provided free education for the poor, with, of course, a Wahabi curriculum. At the same time, young men from the poorer Muslim countries, such as Egypt and Pakistan, who had felt compelled to find work in the Gulf to support their families, associated their relative affluence with Wahabism and brought this faith back home with them, living in new neighbourhoods with Saudi mosques and shopping malls that segregated the sexes. The Saudis demanded religious conformity in return for their munificence, so Wahabi rejection of all other forms of Islam as well as other faiths would reach as deeply into Bradford, England, and Buffalo, New York, as into Pakistan, Jordan or Syria: everywhere gravely undermining Islam's traditional pluralism. $^{11}$

By the dawn of the 21st century, the prestige of Wahabi ideology from new seminaries in Medina and Jeddah outshone traditional Islamic centers of learning like those of Damascus and Cairo. The center of Sunni Muslim scholarship and one of the oldest universities in the world, Al-Azhar University, was not spared. When its current president Dr. Ahmad Al-Tayyib rose to the rank of university president in 2003, he readily admitted the loss of Al-Azhar's prestige and its centrist Islamic worldview, and blamed the institution's fall from grace on Wahabi-Salafi infiltration spreading throughout Egypt. ${ }^{12}$ This brings us to the emergence of the Wahabi-Salafi synthesis.

\section{From Arabia to Egypt: The Wahabi-Salafi Synthesis (1902-1967)}

By the early 20th century, the spread of Wahabi ideology had organized the preoccupation of many scholars with the founding fathers of Islam (i.e. the salaf) into a new academic, theological and political school

\footnotetext{
11 The fate of Hashemite royalty varied greatly between these three nations. Their power over Syria not last even one year before the French bombed out of their new sphere of influence. In Iraq the Hashemite monarchy lasted until 1958, and the Hashemite Kingdom of Jordan remains until today.

${ }^{12}$ For more on this see Hani Nasira, "Salafists challenge al-Azhar for ideological supremacy in Egypt," The Jamestown Foundation, September 16, 2010.
} 
broadly called Salafism. This school is sometimes identified with Neo-Traditionalist or Fundamentalist Islam. ${ }^{13}$ Salafism as a school emerged — believe it or not—out of Islamic Modernism, a precursor and rival school in Egypt seeking to reconcile Islamic tradition with modern, secular and scientific values out of Europe. At the time, Egypt was the most populace, modern and technologically advanced state in the greater Middle East, and so it comes as little surprise that it was also the intellectual center of Arabic and Islamic thought.

Islamic Modernists, including the eminent Muhammad 'Abduh (d. 1905) of al-Azhar University, had to make room for the doctrines of the salaf and tawhid-made famous by Ibn 'Abd al-Wahab and Ibn Taymiyyah—while marketing his rationalist revival of Islam. ${ }^{14}$ His student M. Rashid Rida (d. 1935) of Syria, who was deeply moved by the struggle for Arab national identity as well as Islamic solidarity, represents a midpoint between the rationalist and fundamentalist impulses of Islamic political thought at the time. Following Rida Salafism not only spread in the region but became institutionalized, much at the expense of the short lived Islamic Modernist experiment. Different currents of the school would emerge including Salafi-Intellectualism (al-salafiyyah al-'ilmiyyah) and a Salafism-Missionary variety (al-salafiyyah al-da'awiyyah). The vitality of Salafism came as a direct result of the political turmoil of the first half of the 20th century. The Arabs of the Middle East and Muslims throughout the world were plunged into a state of crisis in the wake of the First and Second World War. Two existential calamities befell the people of the region.

(1) The British and French carve up the Ottoman Middle East into smaller states (Sykes-Picot 1916), leading to the abolishment of the Islamic Caliphate (1924);

(2) The British unilaterally establish a new state called Israel over historic Palestine (Balfour 1917; 1948).

European colonialism had dealt the people of the region two decisive blows. The caliphate represented the seat of universal Islamic political authority and symbolic leadership. Its destruction meant the members of the global Muslim community were cut off from its center, and from one another. It also severely mitigated the role of Islamic law (shari'ah) in the lives of everyday Muslims. The creation of Israel against the will of the native Arab population was seen as fundamentally illegitimate, and lead to a series of destructive Israeli-Arab wars beginning in 1948. Various forms of nationalism and Islamism took hold as a means of protest and resistance. There developed within the Muslim community a deep nostalgia for the Caliphate, as well as deep resentment of the Israeli state and its creators in the West. With the humiliating loss of Egypt and its Arab allies to Israel in the 1967 war, and the subsequent Israeli occupation of Sinai, Gaza, the West Bank and Golan Heights, Arab Nationalism lost its popular support, allowing politicized forms of Islamic activism to take center stage. In order to reclaim the Arab lands lost to the Zionist enemy activists from within the Salafi school called for Jihad and the return of the Islamic Caliphate. This branch of Salafism merged with Wahabi ideology and formed a Wahabi-Salafi synthesis. It was the birth of Jihadi-Salafim (al-salifyyah al-jihadiyyah), and it articulated itself in the form of groups of political resistance.

\footnotetext{
${ }^{13}$ Works abound on the rise of Salafism and its contribution to the "Salifization" of modern Islamic tradition. The resulting problem of Islamic fundamentalism in the Middle East especially is best viewed from within societies where Salafism was active since the 1980s. Cf. e.g. Burhan Ghalioun, Ightiyal al-‘aql: mihnat al-thaqafah al-‘arabiyyah bayn al-salafiyyah wa al-tab’iyyah, al-Markaz al-Thaqafi al-'Arabi, 2004; Sadiq J. Al-'Azm, Naqd al-fikr al-dini, Beirut: Dar al-Tali'ah, 1982, trans. Critique of Religious Thought, Berlin: Gerlach, 2014.

${ }^{14}$ Abduh's teachings on the salaf and their pristine, ancient way of life (salafiyyah) took on far greater importance in the thought of his student Rashid Rida (d. 1935), a vehement neo-traditionalist. For more on this see Albert Hourani, The Emergence of the Modern Middle East, Berkeley; Los Angeles: University of California Press, 1981, 90-91. Abduh himself was a neo-rationalist (neo-Mu'tazilite) whose most famous work, The Theology of Unity [Risalat al-tawhid], trans. Kennth Cragg, Selangor, Malaysia: Islamic Book Trust, 2003 framed unity (tawhid) in more rationalist terms than later Salafis would understand.
} 


\section{The Failure of Arab Nationalism and the Rise of the Muslim Brotherhood, 1928-1979}

In Egypt, the founding of the Muslim Brotherhood in 1928 by Hasan al-Banna (d. 1949) and its radicalization through the works of Sayyid Qutb (d. 1966) transformed Salafism from a school of thought into an institution of political resistance. Qutb, who in the 1940s visited both Europe and the Unites States, was not seduced by its modern trappings, but rather appalled by, what he describes as, its racism, individualism, materialism, sexual freedom and-most of all—its unwavering support of Israel. ${ }^{15}$ Unlike his rationalist predecessor, Muhammad 'Abduh who was infatuated by French ballroom dancing, Qutb introduced the idea that all modern western decadence and injustice constituted a new era of darkness (jahiliyyah). And Islam was the light. ${ }^{16}$

Qutb was executed in 1966 under the Egyptian military state of president Gamal Abdel Nasser (d. 1970). He became a martyr overnight strengthening the zeal and motivation of the Muslim Brotherhood, which was increasingly driven underground. The repression of the state against any alternate resistance movement-i.e. the Muslim Brotherhood-exacerbated their political resistance. New branches of the Muslim Brotherhood sprouted up in Syria, Jordan and the Palestinian group known as Hamas, founded in 1987 to combat the Israeli Defense Forces (IDF), is itself an offshoot of the Muslim Brotherhood.

Jihad against Zionist and Western "occupiers" soon came to include the increasingly authoritarian Arab regimes themselves. This was especially the case, following the single substantive Arab military victory over Israel in 1973, when Egyptian president Anwar Al-Sadat (d. 1981) and prime-minister Menachim Begin (d. 1992) signed the Camp David Accords in 1978 and the Egypt-Israel Peace Treaty of 1979. The deal not only opened up diplomatic and commercial links between both nations, but brought them into a common American sphere of influence. After its number one ally in the region-Israel—Egypt has historically come in second receiving $\$ 1.3$ billion in US military aid every year. ${ }^{17}$ In the eyes of some segments of the Arab and Muslim public, Egypt had made a deal with the devil, and there would be dire consequences.

Attempts by president Anwar Al-Sadat (d. 1981) to loosen the state’s grip on growing Islamic opposition movements could not save his life. In 1981, he was assassinated and hundreds of Muslim Brothers were incarcerated in connection with the murder, including none other than Ayman Al-Zawahiri, current Emir of Al-Qaeda.

\section{The Impact of the Iranian Revolution 1979}

In 1979, the US both gained as well as lost allies in the Middle East. That year saw the controversial peace deal between Egypt and Israel. However, it also saw the toppling of the Mohammad Reza Shah (d. 1980) - largely seen as an American puppet—by popular and later Shi'ite Islamist leaders. The Islamic Revolution under the guidance of Ayatollah Ruhollah Khomeini (d. 1989) represented the single most decisive act of national, political resistance to Western, and later Zionist intervention, in the region.

The Islamic Republic of Iran introduced Islam as a viable, powerful and legitimate political alternative to the despotic and ineffective nationalist regimes. It sent shockwaves throughout the Middle East. The Muslim

\footnotetext{
${ }^{15}$ For more on Qutb's rejection of perceived earthly vices and western political encroachment see John Calvert, Sayyid Qutb and the Origins of Radical Islamism, Oxford; New York: Oxford University Press, 2009, 152-55, 171, 188, 286, 326.

${ }^{16}$ Ibid., 217-224, 333.

17 For more on this see C. Mullen, “The geopolitics of revolution” in Revolutionary Egypt: Connecting Domestic and International Struggles, ed. Reem Abou-El-Fadl, London; New York: Routledge Press, 2015, 190-91.
} 
Brotherhood were more determined than ever to assert political power. This caused the Egyptian state much anxiety, which all the while had given sanctuary to the exiled, broken and dying former Shah of Iran. Saudi Arabia, with its council of Wahabi elders, was alarmed by the rise of a new and formidable Shi 'ite rival in the region. Sunni students from around the world, including Egypt and Syria, flocked to the seminaries of the Kingdom, including the University of Medina, and returned to their home countries imbued with Wahabi ideology and in some cases a propensity for Salafi-Jihadism. Even the prestigious Al-Azhar University of Egypt was poisoned by Wahabi influence (see earlier). ${ }^{18}$

The Islamic Republic of Iran also had a crucial impact on Iraq and Syria. Once Egypt had quit the fight against Israel, so to speak, the last gasps of Arab Nationalism lived on in the Ba'ath parties of both Syria and Iraq. Furthermore, as a result of earlier British and French colonial policy the Sunni minority in Iraq and the Alawite (Shi'ite) minority of Syria put Ba'ath against Ba'ath. ${ }^{19}$ For obvious reasons, with less then obvious future consequences, the Iraqi regime of Saddam Hussein (d. 2006) stood against Iran. Whereas the Syrian regime of Hafez al-Assad (d. 2000) made Iran its new strategic partner, instead of Egypt. Another seismic shift had taken place in the region, this time raising sectarian as well as Jihadi tensions.

\section{Social Injustice and Jihad Against the Arab States, 1979-2011}

Arab Nationalism was all but dead. And new strategic partnerships threatened the status quo. Arab regimes as a whole grew increasingly threatened and repressive. Any and all forms of opposition, minority activism and religious mobilization were brutally crushed by the state. For countries like Egypt and Iraq, however, the strong arm of the police state assured some measure of economic prosperity and political stability through the 1980s. ${ }^{20}$ Nevertheless, the complete lack of freedom, increasing corruption by the elite and declining economic fortunes for the working class resulted in endemic, choking and perpetual social injustice.

Beginning in the 1990s, the conflict between the Arab police state and its mirror image, militant Salafi-Jihadism emerged. As they say, "for every action, there is an equal and opposite reaction." In Egypt, the more the state cracked down, the more terrorist attacks shook the countries once thriving tourist industry. The ever watching eye of the Interior Ministry's police deliberately and preemptively profiled and targeted youth gathering at mosques after Friday prayers, those staying out late at night and especially conservative men wearing beards and dawning religious garb. As a result, mosques were locked up except for the prayer intervals 5 times a day, and all fashions of street peddlers, student activists, juvenile delinquents or anyone caught at the wrong place at the wrong time could be imprisoned, tortured and tried in military courts. Police brutality was the powder keg of Arab State repression. It comes as no surprise, therefore, that the popular revolutions in Tunisia and Egypt in 2010-2011 were triggered by two horrific episodes of police brutality. ${ }^{21}$

Throughout the 1990s and early 2000s, citizens of repressive Arab states were increasingly stuck between a rock and a rock place. And the US was itself knowingly complicit in their suffering and misery. Dictatorship

\footnotetext{
18 Hani Nasirah, “Hamlat shaykh al-azhar 'ala al-salafiyyah,” Al-Arabiyya, October 28, 2010.

${ }^{19}$ Cf. generally Eberhard Kienle, Bath v. Bath: The conflict between Syria and Iraq, 1968-1989, London; New York: I.B. Taurus, 1990.

20 The point here is that socio-economic indicators under Saddam Hussein (d. 2006) and Hosni Mubarak were not all bad, and in some cases very good. One useful example is Iraqi public education prior to 1991, which was one of the best in the Middle East. For more on this see United Nations Educational Scientific and Cultural Organization, Iraq, Education in Transition: Needs and Challenges, 2004, Paris: Division of Educational Policies and Strategies, 2004, iii, 2, 87, 105-10.

21 The Tunisian revolution started after the self-immolation of a street vender named Mohamed Bouazizi on December 17, 2010, after he was humiliated by a police officer and prevented from making a living. Just a few months earlier in June 6 a young man named Khaled Saeed was beaten to death by Egyptian police bringing the whole country to a boiling point, and paving the way for the Egyptian Revolution in January 25, 2011.
} 
was a muddy and brutal business, but it guaranteed stability for US interests. These interests included growing the US energy, defense and aerospace industries, controlling the flow of oil to the international market, weakening Iran's influence in the region, and giving Israel cart blanche to build illegal settlements in the West Bank. $^{22}$ Anti-US sentiment spread among the public—Jihadist and pacifist alike—-because the Whitehouse and Pentagon propped up and empowered brutal dictators against their own people. Foreign critics of the US were not, as some politicians have claimed, jealous of "our freedom."23 But what about freedom? Freedom was an excellent talking point, but the prospect of a new, democratic and unknown government would be too risky for the US, who among many things helped topple Iran's first democratically elected prime minister Mohammad Mosaddegh (d. 1967) in 1953. ${ }^{24}$

\section{Jihad as Local Popular Resistance: Hezbollah and Hamas, 1982-}

Between 1979-2007, there were three main conflict zones that devastated the greater Middle East and-as an immediate consequence-empowered both state as well as non-state actors to declare Jihad against (1) Israel, (2) the former USSR and (3) the United States.

Among the Israeli-Arab wars is the former's invasion of Lebanon in 1982, which was part of the long and bloody Lebanese civil war fought between 1975-1990. Leaving aside the details of this conflict, the occupation of Shi'a dominated southern Lebanon gave rise to a local resistance movement called the Islamic Jihad Organization (IJO). Iran became its permanent backer and the group changed its name to Hezbollah (lit. "the party of God"). Prior to its involvement in the Syrian civil ca. 2012, Hezbollah enjoyed ample popular support among Arab as well as Islamic societies because it represented the people’s resistance against Israeli aggression and occupation. Its guerilla tactics including the suicide bombing of Israeli military targets, however, have gained it the reputation of a terrorist organization by Israel, the US, EU, GCC and other Western and Sunni state actors. Using similar guerilla tactics including suicide bombings, the Sunni Islamic resistance group known as Hamas now in control of the Gaza Strip historically enjoyed the support of its constituents, as well as Arabs and Muslims abroad. And when popular support has faltered on account of Hamas' belligerence, Israel's wholesale destruction of Gazan civilians and infrastructure in 2004, 2006, 2008 and 2014 re-affirmed this support all over again.

Hamas and Hezbollah may be considered terrorist organizations to Western nations whose interest they threaten, but they have been and remain, for better or worse, state actors in the Middle East for well over 30 years. Their call to Jihad against Israeli aggression, moreover, especially the suffocating blockage of Gaza since 2006, has received a great deal of sympathy and popular support. But that's not all. Supporting Jihad against Israel has itself become a deeply divisive force in the Middle East. Iran's presence in the Levant through Hezbollah, has made Hamas a political football between other states in the region. ${ }^{25}$

22 See Mitchell, Carbon Democracy, 159-61, 219.

23 The original source of this misinformation came in a speech by George W. Bush on September 20, 2001 in which he claimed about the 9/11 perpetrators and Al-Qaeda, "They hate our freedoms: our freedom of religion, our freedom of speech, our freedom to vote and assemble and disagree with each other.” For a full transcript of the speech see "Transcript of President Bush's address," CNN, September 21, 2001.

${ }^{24}$ Saeed Kamali Dehghan and Richard Norton-Taylor, “CIA admits role in 1953 Iranian coup,” The Guardian, August $19,2013$.

25 In the wake of the second Palestinian uprising or Intifada in 2002, as well as the US led war on Iraq in 2003, the Middle East was rendered more unstable as a result of the remaining power vacuum. Among Iran's activity to fill this power vacuum was increasing support for Hezbollah, whose Shiite faith and military competence in the wake of its war with Israel in 2007 threatened both Israel and Sunni regional dominance influence. Therefore on the question of Palestine, Qatar and Turkey intervened more directly to support Hamas. For more on this see Sara Roy, Hamas and Civil Society in Gaza: Engaging the Islamist Social Sector, Princeton; Oxford: Princeton University Press, 2011, 241-62. 


\section{From Cold War to Gulf War, 1979-2007: The Taliban and Al-Qaeda}

The Cold War was fought-among other places_in the Middle East. Governments as well as anti-government rebel groups received American and Soviet military, logistical and political support. The immediate consequence of playing this dangerous game was the collapse of states, which to date have never fully recovered, creating deadly power vacuums. The indirect consequence, however, was the renewed call to Jihad yet again — this time against the interventionism of the Soviets and Americans on opposing sides-and the subsequent globalization of Salafi-Jihadi operations, culminating in Al-Qaeda. ${ }^{26}$

The Soviet War in Afghanistan (1979-89) brought about a people's resistance supported by the US and known to the world as the Mujahideen (lit. "those who undertake Jihad”). Presidents Jimmy Carter and later Ronald Reagan (d. 2004) were directly supporting Jihad in Afghanistan to the tune of billions of dollars. On the ground the Soviets met with stiff resistance from an alliance of native Afghani Pashtuns, foreign Jihadi-Salfist fighters coming mainly from Arab states, and president Zia-ul-Haq (d. 1988) of Pakistan who had no qualms about manipulating Jahadist groups for military gains. Among the ranks of the Salafi-Jihadists was a towering figure from a well respected Saudi family who came to lead the Mujahideen. This was none other than Osama bin Laden (d. 2011). Having helped win the war against the Soviets, Bin Laden was determined to continue his campaign of Jihad in other conflicts. He had the personal wealth, leadership and prestige to start the organization called the “Jihadist base camp” (qa 'idat al-jihad), otherwise known as Al-Qaeda. After attempts to set up Al-Qaeda in Sudan, Bin Laden was denounced by the Saudi government in 1992, and he was forced back into Afghanistan where starting in 1996 it thrived under the support of Mullah Umar and the Taliban government. From Chechnya, Bosnia, Kashmir and wherever he perceived that political struggles threatened Muslim lives, Global Jihad now had a permanent home in the mountains Tora Bora.

This period was no less tumultuous for Iraq or Iran. A staple of US foreign policy in the region, since the overthrow of the Shah in 1979 and until today, was regime change in Iran. The Whitehouse befriended president Saddam Hussein of Iraq and helped bankroll his military mayhem and massacres for an entire decade. Iraq invaded Iran, and the war lasted eight long years from 1980 to 1988 making it one of the longest in the 20th century, and resulting in more than one million lives lost. ${ }^{27}$ The war also sowed the seeds of sectarian conflict for decades to come, between Sunni and Shia, and between Arab and Persian. The US and its European allies supplied Saddam with the "weapons of mass destruction" they later demanded he turn over. ${ }^{28}$ Saddam $^{2}$ used his newfound military might to crack down on Iraqi Shi'ite’s allied with Iran as well as Iraqi Kurds. The regime executed hundreds in the infamous Dujail massacre of 1982 and brought ruin upon the Shi'ite south for years to come. Saddam's arsenal also included chemical weapons which he used to massacre about 10,000 Kurds in the city of Halabja in 1988.

In 1990, the Middle East went through another seismic shift. Iraq invaded Kuwait, disrupting the flow of oil to the international market. This act of aggression posed an immediate threat to Saudi as well as American interests. The first Gulf war in 1991 saw the liberation of Kuwait, the punishing defeat of the Iraqi army but also crippling economic sanctions which killed a million Iraqi civilians from 1991-1998 alone—half of whom

\footnotetext{
${ }^{26}$ See the chapter titled “McJihad” in Mitchell, Carbon Democracy, 200-30.

27 Ian Black, "Iran and Iraq remember war that cost more than a million lives," The Guardian, September 13, 2010.

${ }^{28}$ For more on this Cf. e.g. Seymour Hersh, "U.S. Secretly Gave Aid to Iraq Early in Its War Against Iran,” International New York Times, January 26, 1992.
} 
were children. ${ }^{29}$ However, the US invasion of Iraq and the remainder of thousands of US troops on Saudi soil made both nations enemy number one for Al-Qaeda. Al-Qaeda and affiliated groups were responsible for the bombings of the US embassies in Nairobi and Dar es Salaam in 1998, a host of attacks on Jeddah and Riyadh in the early 2000s, and the attacks on the World Trade Center and Pentagon September 11, 2001.

\section{George W. Bush}

In the coming weeks, months and years, the intensification of US military intervention in the region would fuel Salafi-Jihadism like never before. President George W. Bush waged a global “war on terror,” beginning in 2001, against the Taliban, and then brought "shock and awe” to Saddam's Ba'ath regime in Iraq in 2003. Bush's rhetoric, furthermore, fed right into the clash of civilizations worldview espoused by Salafi-Jihadism, describing his war as a "crusade” in September 17, 2001, and proclaiming to the world three days later, “you're either with us or you're with the terrorists." ${ }^{30}$ To add fuel to the blaze, the war on Iraq was illegal and based on falsified evidence. In other words, the war received the condemnation of the UN secretary general Koffi Anan; there were no "weapons of mass destruction;" and everyone knew that it was impossible for Saddam Hussein to have any connection with Osama Bin Laden. ${ }^{31}$

In 2002, the US opened up the Guantanamo Bay Detention Camp and filled it with prisoners from the so-called war on terror. Some were Salafi-Jihadists and Al-Qaeda types, but the overwhelming majority were not guilty of any crime approaching terrorism. Many were subjected to torture, otherwise ascribed the euphemism "enhanced interrogation techniques." ${ }^{32}$ Similarly in 2003, widespread US military violations surfaced in the Abu Ghraib torture scandal. Repressive states in the Middle East were now taking cues from the Bush administration and began new crackdowns, as well as shared, controversial "extraordinary rendition" programs. The Senate Intelligence Committee report on CIA torture released December 9, 2014 gives us a taste of just how much terror was committed in the name of the war on terror between 2001-2006.

During this time, the floodgates of Jihad were burst open. Al-Qaeda spread from Afghanistan to Iraq, Yemen, Somalia and the Maghreb. The new phenomenon, furthermore, of filming the executions of western prisoners bound in orange jump suits was inspired—for lack of better words—by Guantanamo. ${ }^{33}$ Once again, for every action, there is an equal and opposite reaction.

The Bush administration destroyed the Ba'ath regime and its military, which were Sunni, and they empowered the embittered Sh'ia in their stead. The popular Sunni insurgency (ca. 2003-2007) raged in Al-Anbar province between various militias and former Ba'ath members on one hand and the US armed forces on the other. The call to Jihad against "American crusaders" in Iraq was so strong, that even grand mufti of Al-Azhar University, Muhammad Sayyid Tantawy, gave it his blessing. Some Arab governments, especially the Assad regime in Syria, tacitly gave a blind to hundreds (thousands?) of foreign fighters entering Iraq. However, the Sunni insurgency was quickly overcome by Al-Qaeda in Iraq. Nevertheless, in 2006, the US succeeded in assassinating Bin Laden’s man in Iraq, the Jordanian Abu Mus‘ab al-Zarqawi (d. 2006). On May

\footnotetext{
${ }^{29}$ Christian Scherrer, "US-UK Engineered Genocide by Sanctions against Iraq 1990-2003 and Its Ongoing Deadly Legacy” in Iraq: Genocide by Sanctions, ed. Christian Scherrer, Pulau Pinang, Malaysia: Penerbit Universiti Sains Malaysia, 2011, 30-71.

30 “Transcript of President Bush’s address,” CNN, September 21, 2001.

${ }^{31}$ By 2004 the US led war against Iraq had been completely discredited. Cf. e.g. Walter Pincus and Dana Milbank, “Al Qaeda-Hussein Link Is Dismissed,” The Washington Post, June 17, 2004.

${ }^{32}$ For more on this see Molly Moore, "Report gives details on CIA prisons,” The Washington Post, June 9, 2007.

33 Dan Lamonte, “Once again, militants use Guantanamo-inspired orange suit in an execution,” The Washington Post, August 28, 2014.
} 
2, 2011 Bin Laden himself was assassinated in northeastern Pakistan, in the top secret and later much publicized seal team six operation. Perhaps that should have been the end of it. But something much worse was on the horizon.

\section{The Syrian Civil War and the Rise of ISIS, 2011-}

2011 marks the most recent seismic shift in the region. Decades of repression, social injustice and economic misery sparked popular revolutions in Tunisia and Egypt. Demonstrations in other Arab countries, however, especially Libya, Syria, Yemen and Bahrain were immediately crushed by the police, intelligence and military. The Whitehouse was caught completely off guard and floundered in its attempts to understand, let alone control, the ensuing chaos in the region. US president Barack Obama, as well as some GCC allies, was quick to flood Libya with heavy arms to overthrow Muammar Gaddafi (d. 2011), but then reticent to intervene decisively in Syria, where approximately 300 thousand people have been killed in over five years. ${ }^{34}$ Gaddafi was killed but Libya was now awash in heavy arms and militias with ties to the fractured parliament were making civil war. US arms flooded several Arab states, including Syria, Yemen and Mali, helping Al-Qaeda to grow to the point of critical mass.

In Syria, it was the Al-Qaeda affiliated Salafi-Jihadists who had been the most organized and most powerful force on the ground. By late 2011, peaceful demonstrators assembled in Damascus, Aleppo and other cities, repeating the Egyptian mantra "the people want the fall of the regime," while rural communities in Homs, Hamah and elsewhere gathered around Salafi-Jihadist emirs crying out, "we want Syria to be an Islamic caliphate.”35 Unlike the fractious secular opposition—-the Syrian National Council (SNC)—Al-Qaeda in Syria gained grass roots support. Their brigades were many to begin with, but came to be dominated in 2012 by the Nusra Front (jabhat al-nusra) which have fought with, and lead, the Free Syrian Army (FSA; the so called "moderate opposition") in battle against the Assad regime.

Meanwhile in Iraq, the Sunnis were crying foul at the injustice and corruption of president Nouri al-Malki, a Shi'ite. Sectarian violence was at a horrific new high. Al-Qaeda was mobilizing under new leadership. It was re-branded in 2006 as the Islamic State in Iraq (ISI) and received immediate criticism from headquarters in Afghanistan. The instability in neighboring Syria, and the Jihadi network established between the two countries since the second Gulf war (see earlier), allowed ISI entrance into the Syrian civil war in April 2013, thereby calling itself the Islamic State in Iraq and the Levant/al-Sham (ISIL, ISIS). It came into immediate conflict with the Nusra Front until borders between the two solidified. The ranks of ISIS were swollen further following the popularly supported military coup in Egypt on June 30, 2013, which overthrew the first ever democratically elected president Muhammad Morsi and drove his party, the Islamic Brotherhood, underground once again. ${ }^{36}$ In any case, under the direction of its mysterious leader, Abu Bakr al-Baghdadi, ISIS conquered the Syrian city

\footnotetext{
${ }^{34}$ See "320,000 people killed since the beginning of the Syrian Revolution” The Syrian Observatory for Human Rights, June 9, 2015. With a death toll of approximately 300 thousand the Syrian civil war (2011-) has surpassed the death tolls for the North Yemen civil war (1962-1970), Lebanese civil war (1975-1991), Algerian civil war (1991-2004) and ongoing Iraqi civil conflict (2003-).

${ }^{35}$ There are a number of online videos to this effect dating from late 2011 and early 2012, i.e. before the tidal wave of Salafi-Jihadism came to dominate large swaths of the Syrian countryside and cities in the east. See also "Arabi Wadili, "Amir al-zabadani-Min hilm al-khilafah ila al-bahth 'an malazz,” Al-Safir, August 29, 2015.

36 The rejection and forcible dismantling of democratically elected Islamist governments is not without precedent in the region, where Hamas was isolated and after their 2006 electoral victory in Gaza in 2006, and which followed the 1990 electoral victory of the Front Islamique du Salut in Algeria was aborted by the military, leading to the country's bloody civil war.
} 
of al-Raqqa in 2013 and descended upon Mosul on June 9th 2014, which immediately capitulated after years of repression from the Malki regime. ISIS then changed its name to simply the Islamic State (IS) and al-Baghdadi appointed himself caliph-answering the call of radicalized and dejected youth calling for the return of the caliphate since 2011. This was the fruition of prophecy. ${ }^{37}$

Hardened by a decade of merciless sectarian warfare, funded by wealthy Salafi-Jihadist interests and determined to bring about the foretold end of days in Syria, ISIS fighters have massacred, tortured, raped, enslaved and desecrated people as well as world heritage. Despite the pornography its violence, ${ }^{38}$ we should keep in mind that the scale of ISIS' barbarism is merely that of any war-including the war on terror (see earlier). Yet this scale is far less than that of the Assad regime. ${ }^{39}$ War is inherently an act of extermination. As the well known statement attributed to Bertrand Russel states, "War does not determine who is right, only who is left." 40

However, ISIS commits atrocities all in the name of Islam. How is this possible?

\section{Finding Answers}

I take you back to the very beginning of this paper, to the iconoclasm of Ibn 'Abd al-Wahab, the sectarianism of Ibn Taymiyyah, and the sacred history of the Hadith tradition and cherry picked Qur'an verses. These very traditions-among others-are explicitly cited as justification by ISIS in its execution videos. The reason that Salafi-Jihadist groups generally, and Al-Qaeda and ISIS specifically, have recourse to such traditions is because they were recorded during times of war. That is to say Ibn 'Abd al-Wahab's ideology allowing Muslims to kill Muslims functions in a historical bubble where warfare between neighboring tribes was the norm. Similarly, Ibn Taymiyya’s incitement against the Shi'a came as a direct result of their perceived collaboration with the Mongols who had recently and brutally conquered the region-i.e. during the major medieval seismic shift in the Middle East. The same analogy can be made with the Hadith traditions, which many claim go back to the salaf, especially Abu Bakr (d. 634) and Khalid b. al-Walid (d. 642) whose wars of apostasy (hurub al-riddah) represent large scale tribal warfare. These are dark episodes of history, but for Salafi-Jihadists who hold history itself as sacred, it offers an opportunity to articulate their identity and fulfill prophecy.

Furthermore, the spread of Wahabi ideology along well established networks of medieval scholarship and modern oil economies, coupled with the European conquest of the Ottoman empire, tied the dream of the caliphate' return with the act of Jihad, and some would add the apocalypse. ${ }^{41}$ Of course, the main reason such ideas are even remotely persuasive among the segments of youth in the region is the widespread injustice and economic as well as political unrest. Notwithstanding this fact, I reiterate that all Islamic institutions and even leading members of the Salafi-Jihadist camp have condemned ISIS and its distortion of Islam. ISIS may be a monster, but it is the monster of our own creation and devices. It took decades to make and will take decades to unmake.

\footnotetext{
37 Ali Mamouri, “Did nostalgia for Islamic caliphate become a reality?,” Al-Monitor, July 5, 2014.

38 Simon Cottee, “The pornography of Jihadism," The Atlantic, September 12, 2014.

39 Hugh Naylor, “Islamic State has killed many Syrians, but Assad's forces have killed more,” The Washington Post, September 5, 2015.

40 The wisdom behind this quote pierces deeper than its apocryphal origins on BrainyQuote.com. http://www.brainyquote.com/quotes/quotes/b/bertrandru101224.html.

${ }^{41}$ For more on this see Graeme Wood, "What ISIS really wants," The Atlantic, March 2015.
} 
One thing amply demonstrated in this paper is that religion is not the only factor in the problem of ISIS in the Middle East. Its root causes may be expressed as follows:

(1) Oil rich Arab Gulf states packaging and exporting Wahabi-Salafi ideology as though it were mainstream Islam;

(2) The repression of Arab police states, economic hardship and lack of social justice;

(3) Western—often US and Israeli—military intervention, destabilizing the region.

\section{References}

320,000 people killed since the beginning of the Syrian Revolution. The Syrian Observatory for Human Rights. June 9. Retrieved October 27, 2015, from http://www.syriahr.com/en/2015/06/09/19768

Abduh, M. (1905). Risalat al-tawhid. Trans. (2003). The theology of unity. Selangor, Malaysia: Islamic Book Trust.

Al-‘Azm, S. (1982). Naqd al-fikr al-dini, Beirut: Dar al-Tali ‘ah. Trans. (2014). Critique of religious thought. Berlin: Gerlach.

Armstrong, K. (2014). Wahabism to ISIS: How Saudi Arabia exported the main source of global terrorism. New Statesman.
November
$27 . \quad$ Retrieved
October
27,
2015
from http://www.newstatesman.com/world-affairs/2014/11/wahhabism-isis-how-saudi-arabia-exported-main-source-global-terrori $\mathrm{sm}$

Black, I. (2010). Iran and Iraq remember war that cost more than a million lives. The guardian. September 13. Retrieved October 27, 2015, from https://www.theguardian.com/world/2010/sep/23/iran-iraq-war-anniversary

Calvert, J. (2009). SayyidQutb and the origins of radical Islamism. Oxford; New York: Oxford University Press.

Cottee, S. (2014). The pornography of Jihadism. The Atlantic. September 12. Retrieved October 27, 2015, from http://www.theatlantic.com/international/archive/2014/09/isis-jihadist-propaganda-videos-porn/380117/

Dallal, A. (1993). The origins and objectives of Islamic revivalist thought, 1750-1850. Journal of the American Oriental Society, 113(3), 341-359.

Dehghan, S., \& Norton-Taylor, R. (2013). CIA admits role in 1953 Iranian coup. The guardian. August 19. Retrieved October 27, 2015, from https://www.theguardian.com/world/2013/aug/19/cia-admits-role-1953-iranian-coup

DeLong-Bas, N. (2007). Wahabi Islam: From revival and reform to global jihad. London; New York: I.B. Taurus.

Eaton, R. (1993). The rise of Islam and the Bengal frontier, 1204-1760. Berkeley; Los Angeles; London: University of California Press.

Ghalioun, B. (2004). Ightiyal al-‘aql: mihnat al-thaqafah al-‘arabiyyahbayn al-salafiyyahwa al-tab’iyyah. al-Markaz al-Thaqafi al-‘Arabi, 2004.

Hersh, S. (1992). U.S. secretly gave aid to Iraq early in its war Against Iran. International New York Times. January 26. Retrieved $\begin{array}{llll}\text { October 27, 2015, from } & 27, \text { f }\end{array}$ http://www.nytimes.com/1992/01/26/world/us-secretly-gave-aid-to-iraq-early-in-its-war-against-iran.html?pagewanted=all

Hodgson, M. (1977). The venture of Islam, Volume 2: The expansion of Islam in the middle periods. Chicago: University of Chicago Press.

Hourani, A. (1981). The emergence of the modern Middle East. Berkeley; Los Angeles: University of California Press.

Kienle, E. (1990). Bath v. Bath: The conflict between Syria and Iraq, 1968-1989. London; New York: I.B. Taurus.

Lamonte, D. (2014). Once again, militants use Guantanamo-inspired orange suit in an execution. The Washington Post. August 28. $\begin{array}{llll}\text { Retrieved } & \text { October } & 27, & 2015,\end{array}$ https:/www.washingtonpost.com/news/checkpoint/wp/2014/08/28/once-again-militants-use-guantanamos-orange-jumpsuit-i n-an-execution/

Mamouri, A. (2014). Did nostalgia for Islamic caliphate become a reality? Al-Monitor. July 5. Retrieved October 27, 2015, from http://www.al-monitor.com/pulse/originals/2014/07/iraq-isis-salafist-nostalgia-islamic-caliphate.html

Mitchell, T. (2011). Carbon democracy: Political power in the age of oil. London; New York: Verso Books.

Moore, M. (2007). Report gives details on CIA prisons. The Washington Post. June 9. Retrived October 27, 2015, from http://www.washingtonpost.com/wp-dyn/content/article/2007/06/08/AR2007060800985.html

Mullen, C. (2015). The geopolitics of revolution. In Abou-El-Fadl (Ed.), Revolutionary Egypt: Connecting domestic and international struggles. London; New York: Routledge Press. 
Nasira, H. (2010). Salafists challenge al-Azhar for ideological supremacy in Egypt. The Jamestown Foundation. September 16. $\begin{array}{llll}\text { Retrieved } \quad \text { October } & 27, & \text { 2015, }\end{array}$ http://www.jamestown.org/single/?tx_ttnews\%5Btt_news\%5D=36865\&no_cache=1\#.V2h6yJMrKEI

Nasirah, H. (2010). Hamlatshaykh al-azhar 'ala al-salafiyyah. Al-Arabiyya. October 28. Retrieved October 27, 2015, from http://www.alarabiya.net/views/2010/10/28/124034.html

Naylor, H. (2015). Islamic State has killed many Syrians, but Assad’s forces have killed more. The Washington Post. September 5. $\begin{array}{llll}\text { Retrieved } \quad \text { October 27, 2015, from } & \text { 27 }\end{array}$ https://www.washingtonpost.com/world/islamic-state-has-killed-many-syrians-but-assads-forces-have-killed-even-more/201 5/09/05/b8150d0c-4d85-11e5-80c2-106ea7fb80d4_story.html

Pincus, W., \& Milbank, D. (2004). Al Qaeda-Hussein link is dismissed. The Washington Post. June 17. Retrieved October 27, 2015, from http://www.washingtonpost.com/wp-dyn/articles/A47812-2004Jun16.html

Roy, S. (2011). Hamas and civil society in Gaza: Engaging the Islamist social sector. Princeton; Oxford: Princeton University Press.

Russell, $\quad$ B. $\quad$ (n.d.). $\quad$ BrainyQuote.com. $\quad$ Retrieved $\quad$ October $\quad 27, \quad 2015$, from http://www.brainyquote.com/quotes/quotes/b/bertrandru101224.html

Scherrer, C. (2011). US-UK engineered genocide by sanctions against Iraq 1990-2003 and its ongoing deadly legacy. In Scherrer, C. (Ed.), Iraq: Genocide by sanctions. Pulau Pinang, Malaysia: Penerbit Universiti Sains Malaysia.

Sciutto, J., Crawford, J., \& Carter, C. (2014). ISIS can “muster” between 20,000 and 31,500 fighters, CIA says. CNN. September 12. Retrieved October 27, 2015, from http://www.cnn.com/2014/09/11/world/meast/isis-syria-iraq/

Transcript of President Bush's address. CNN. September 21. Retrieved October 27, 2015, from http://edition.cnn.com/2001/US/09/20/gen.bush.transcript/

United Nations Assistance Mission for Iraq Human Rights Office. (2014). Report on the protection of civilians in armed conflict in Iraq: 6 July-10 September 2014. Geneva and Baghdad: United Nations and High Commission on Human Rights.

United Nations Educational Scientific and Cultural Organization. (2004). Iraq, education in transition: Needs and challenges, 2004. Paris: Division of Educational Policies and Strategies.

Wadili, A. (2015). Amir al-zabadani-Min hilm al-khilafahila al-bahth 'an malazz. Al-Safir. August 29. Retrieved October 27, 2015, from http://assafir.com/Article/440513

Wood, G. (2015). What ISIS really wants. The Atlantic. March. Retrieved October 27, 2015, from http://www.theatlantic.com/magazine/archive/2015/03/what-isis-really-wants/384980/ 